Jurnal Civic Education, Vol. 1 No. 1 Juni 2017

\title{
PENGEMBANGAN MODEL JURISPRUDENSIAL INKUIRI DALAM PEMBELAJARAN PENDIDIKAN KEWARGANEGRAAN DI SMA NEGERI 10 MANADO
}

\author{
Julien Biringan \\ Dosen Jurusan Pendidikan Pancasila dan Kewarganegaraan FIS UNIMA
}

\begin{abstract}
Abstrak
Penelitian ini memfokus pada pengembangan model jurisprudensial inkuiri dalam rangka memperkuat ketercapaian kurikulum tingkat satuan pendidikan dalam pengajaran PKn di SMA Negeri 10 Manado. Model ini ini sangat penting karena: pertama model ini memperkuat dan meningkatkan mutu proses pembelajaran karena model ini berpusat pada siswa (student active learning), Kedua perkembangan dan eksplosi ilmu pengetahuan tidak lagi memungkinkan pendekatan pembelajaran konvensional yang banyak dilakukan guru-guru selama ini di mana guru menyediakan "bahan jadi" dan siswa siap disuapi. Ketiga katrakteristik mata pelajaran PKn berdasarkan KTSP, memiliki ciri kontekstual. Keempat, perkembangan dan kemajuan teknologi komunikasi dan informasi menghasilkan sangat banyak informasi, masalah ataupun kasus yang dapat diakses oleh siswa, dan model ini memberikan peluang yang sangat luas kepada siswa untuk mengeksplorasi sumber-sumber informasi untuk kepentingan pembelajarannya. Tujuan umum penelitian ini adalah (1) untuk memperoleh gambaran mengenai karakteristik model pembelajaran jurisprudensial inkuiri dalam pengajaran PKn di SMA, (2) langkah-langkah pengembangan model jurisprudensial inkuiri, (3) kekuatan dan kelemahan serta kendala-kendala dalam implementasinya, dan (4) prakondisi yang diperlukan untuk implementasi model ini, dan (5) sejauhmana model ini dapat meningkatkan hasil belajar siswa. Penelitian ini merupakan penelitian pengembangan dalam bentuk Penelitian Tindakan Kelas (PTK). penelitian dan hasil analisis menyimpulkan beberapa hal penting sebagai berikut: (1). Penerapan model Jurisprudensial Inkuiri yang dikembangkan melalui tiga aspek yakni cakupan masalah, sikap siswa dan aspek pelaksanaan penilaian, secara signifikan efektif dan dapat meningkatkan evaluasi proses pada pengajaran PKn. (2). Penerapan model pembelajaran Jurisprudensial Inkuiri dalam kegiatan belajar mengajar di kelas dipengaruhi oleh sejumlah faktor yang determinan. (3). Pengembangan validasi penilaian berbasis portofolio secara signifikan dapat memperkuat ketercapaian evaluasi komprehensif berbasis kompetensi. (4). Melalui penerapan model pembelajaran Jurisprudencial Inkuiri, maka dapat engukur pencapaian tujuan pembelajaran yang cukup baik, dimana terdapat konsistensi sikap dan perilaku dengan pertimbangan-pertimbangan untuk pengetesan asumsi dan penyimpulannya. (5). Implikasi penerapan model pembelajaran Jurisprudensial Inkuiri dapat merangkum strategi pengembangan kurikulum tingkat satuan pendidikan yaitu menyangku guru, lingkungan sosial dan sistem pendukung lainnya.
\end{abstract}

Kata Kunci: Model Jurisprudensial, Inkuiri, Pembelajaran PKn 


\section{PENDAHULUAN}

Pendidikan Kewarganegaraan mempunyai karaktersitik tersendiri yang berbeda dengan mata pelajaran lainnya. Perbedaan itu disebabkan olehnya karakteristik matapelajaran PKn merupakan Pendidikan Nilai atau pun Pendidikan Moral (Moral education). Sebagai suatu bentuk pendidikan nilai, konteks dan perubahan yang terjadi di lingkungan strategis sekolah, membawa perubahan dalam paradigma PKn. Ke depan paradigma baru PKn di arahkan pada pembentukan warganegara yang cerdas (civic intelligence), warganegara yang bertanggungjawab (civic responsibility), dan warganegara yang partisipatif (civic participation) dalam memecahkan masalah bersama, dan dalam upaya membangun kehidupan bersama. Paradigma baru ini akan menjadi tantangan yang sangat serius bagi sekolah terutama guru-guru, karena dari kenyataan-kenyataan empirik teramati kelemahan-kelemahan baik dalam hal pengembangan tujuan pembelajaran, bahan ajar, strategi pembelajaran, maupun dalam sistem evaluasinya. Kelemahan-kelemahan pada unsurunsur strategis tersebut ternyata sangat berpengaruh pada hasil belajar siswa itu sendiri.

Masalah rendahnya mutu pendidikan atau mutu hasil belajar siswa, telah menjadi salah satu masalah nasional di samping masalah efisiensi pendidikan, masalah pemerataan pendidikan, dan masalah relevansi pendidikan. Terhadap masalah-masalah tersebut telah banyak dilakukan upaya-upaya pembenahan baik yang bersifat sistemik maupun instrumental. Pembenahan instrumental yang banyak kali dilakukan adalah pembenahan dan peningkatan mutu proses pembelajaran. Dalam hubungan ini telah dilakukan usaha-usaha untuk mengadopsi inovasi-inovasi pembelajaran seperti student active learning, process skill, inquiry method, problem solving method dan inovasi-inovasi lainnya. Pengembangan dan implementasi berbagai inovasi dalam proses pembelajaran memerlukan upaya yang komprehensif dalam arti didasarkan pada hasil kajian baik kajian teoretik maupun kajian empirik. Dalam arti bahwa proses pembentukan kompetensi itu memerlukan suatu prakondisi yang harus kondusif bagi terselenggaranya pembelajaran yang bermutu, sehingga melalui proses yang bermutu kompetensi yang diharapkan dapat dibentuk. Prakondisi tersebut terutama terkait dengan kemampuan guru-guru dalam mengidentifikasi karakteristik kompetensi setiap mata pelajaran termasuk di dalamnya karakteristik PKn, untuk kemudian mengembangkannya melalui suatu proses pembelajaran sehingga kompetensi itu dapat dibentuk. Kesulitan yang dihadapi ialah ketika tuntutan kontekstualitas kurikulum berbasis kompetensi mensyaratkan bahwa kompetensikompetensi itu harus diidentifikasi, disusun, dirumuskan, dan dikembangkan oleh masingmasing guru sesuai dengan kondisi setiap daerah dan setiap sekolah. Demikian juga dengan faktor-faktor instrumental seperti fasilitas pembelajaran bagi kebutuhan media pembelajaran yang belum tersedia secara memadai akan menjadi kendala-kendala bagi proses pembentukan kompetensi. Keseluruhan faktor-faktor tersebut bermuara pada kebutuhan akan kemampuan guru dalam mengembangkan model pembelajaran yang inovatif, sehingga proses pembentukan kompetensi menjadi lebih efektif.

Sebagai suatu inovasi, model pembelajaran jurisprudensial inkuiri belum banyak dikembangkan sebagai suatu kegiatan sistemik dan sistematis. Di sekolah-sekolah belum cukup banyak berkembang model-model pembelajaran sekalipun kurikulum yang dikembangkan (KBK) mensyaratkan adanya inovasi pembelajaran oleh guru-guru. Masalahmasalah yang masih menjadi kesulitan dalam mengembangkan model pembelajaran inovatif seperti model jurisprudensial inkuiri ialah (1) pemahaman tentang asumsi dan landasan model, (2) pengembangan proses pembelajaran atau langkah-langkah yang merupakan sintaks pembelajaran, (3) pengembangan bahan ajar, dan (4) pengukuran ketercapaian tujuan.

Dengan latar pemikiran yang dikemukakan di atas, maka diperlukan uapayaupaya sistematik dalam mengembangkan inovasi pembelajaran. Hal ini sangat penting karena dari pengamalan empirik teramati bahwa model-model pembelajaran dalam pengajaran PKn oleh guru-guru masih menunjukkan kelemahan-kelemahan yang mendasar. Pertama, 
model pembelajaran yang dikembangkan belum dibangun dan dirumuskan secara konsepsional dalam arti dilandasi oleh landasan-landasan teoretik yang kuat. Kedua, belum menunjukkan komprehensitas kompetensi dalam arti pembentukan kemampuan kognitif, nilai dan sikap, serta keterampilan. Ketiga, model-model pembelajaran yang dikembangkan belum memiliki atau tidak melalui suatu proses validasi empirik dalam arti bahwa model tersebut belum teruji secara empirik mengenai efektivitasnya dalam meningkatkan hasil belajar siswa.

\section{TINJAUAN PUSTAKA}

\section{Konsep dan Pendekatan Inkuiri dalam Pembelajaran}

Barry K Beyer dalam bukunya Teaching Thinking in Social Studies (1979) secara spesifik mengembangkan model pembelajaran inkuiri dalam PKN dan Pendidikan Kewarganegaraan. Konsep PKN atau civic education dilihat sebagai bagian dari social studies) Pendekatan pembelajaran inkuiri oleh Barry Beyer didasarkan pada pengembangan unsur-unsur utama pembelajaran dalam arti optimalisasi unsur-unsur belajar yaitu pengetahuan yang menjadi muatan isyu, problem, informasi, konsep, ataupun asumsiasumsi , (2) afeksi dan nilai yaitu keterlibatan emosional perasaan, semangat, sikap, dan nilainilai, dan (3) proses yang mencakup strategi dalam suatu proses ilmiah seperti merumuskan masalah, mengidentifikasi data, menguji, menganalisis, membuat kesimpulan bahkan pengujian kesimpulan pada data baru yang dinilai bertentangan dengan data sebelumnya. Secara umum model inkuiri Barry Beyer bertolak dari pengembangan unsur-unsur belajar yang digambarkan sebagai berikut:

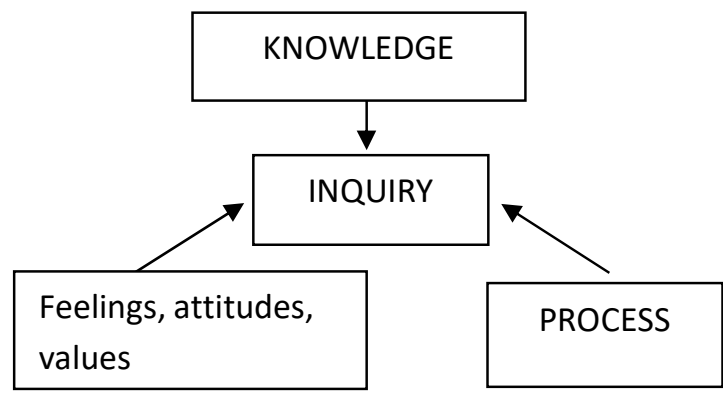

Gambar Unsur-Unsur Inkuiri
Mencermati unsur-unsur tersebut tampak bahwa melalui proses inkuiri dapat ditumbuhkan secara utuh aspek kognitif, afektif, dan ketrampilan. Secara kognitif melalui proses inkuiri siswa diajar untuk mengetahui apa yang menjadi substansi pengetahuan atau materi pelajaran, pengetahuan itu alat bagi kegiatan inkuiri, dan latar belakang pengetahuan yang dimiliki akan mempunyai peranan penting dalam proses inkuiri. Di segi afeksi pada diri siswa akan dapat ditumbuhkan sikap skeptis, ingin tahu, respek pada penalaran, respek pada pembuktian, toleran terhadap ambiguitas, dan obyektif. Di segi proses, siswa di-arahkan untuk mampu mengoperasikan langkah-langkah berpikir ilmiah seperti merumuskan masalah, merumuskan hipotesis, menguji hipotesis, merumuskan kesimpulan, dan membuat generalisasi. Kemampuan mengoperasikan langkah-langkah berpikir ilmiah penting karena model dasar mengajar inkuiri adalah problem oriented. Siswa diajar untuk secara ilmiah dapat memecahkan masalah dengan mengikuti langkah-langkah ilmiah. Bersamaan dengan itu, pada diri siswa dapat ditumbuhkan sikap ingin tahu, skeptis, obyektif, dan respek pada penalaran.

Dalam pengembangan model inkuiri tersebut, Barry K. Beyer (1979) melihat bahwa ada hubungan antara inquiry dan belajar berpikir dalam arti mempelajari teknik berpikir. Beyer menjelaskan hubungan tersebut berdasarkan suatu asumsi bahwa berpikir pada dasarnya terdiri atas dua level operasi kognitif yaitu berpikir makro (proses maupun prosedur), dan ketrampilan mikro yang sangat spesifik yang sangat menunjang proses berpikir makro. Dalam hubungan ini, maka bagi Beyer mengajar inquiry akan memudahkan belajar untuk terampil berpikir. Ketrampilan itu dapat dicapai karena pertama inquiry itu sendiri memberikan kerangka di mana didalamnya dapat dilakukan berbagai aktivitas ketrampilan berpikir baik dalam melakukan interpretasi, analisis, ekstrapolasi, maupun sintesis. Kedua, mengajar inquiry menempatkan siswa dalam suatu situasi di mana mereka harus terlibat di dalam proses inquiry itu sendiri. Ketiga, proses inquiry memberikan kesempatan kepada guru secara sekaligus belajar dan mengajar ketrampilan 
berpikir. Artinya guru tidak hanya mengajar tetapi juga sekaligus terlibat di dalam proses belajar di dalam di dalamnya guru dapat semakin memperoleh pengalaman meningkatkan ketrampilan berpikir baik siswa maupun guru itu senditi. Terakhir, proses inquiry memberi motivasi bagi siswa untuk melatih diri trampil dalam belajar dan untuk trampil berpikir. Melalui proses inquiry siswa akan merasa ditantang dan dimotivasi untuk belajar trampil belajar, dan belajar untuk trampil berpikir.

\section{Pengembangan Model Jurisprudensial Inkuiri Berbasis Isu Publik. \\ 1. Tujuan dan Asumsi}

Model ini didasarkan pada konsepsi mengenai masyarakat di mana sekolah merupakan suatu komunitas masyarakat terbatas, dimana setiap individu (guru, siswa, dan juga pihak-pihak terkait) memiliki perbedaan-perbedaan dalam pandangan, dan oirenstasi nilai yang dapat memungkinkan terjadinya konflik. Pemecahan masalah yang kompleks dan isyu-isyu kontroversial memerlukan warganegara yang mampu secara baik menjembatani berbagai perbedaan nilai sehinggga tidak menimbulkan konflik yang dapat merugikan kepentingan bersama. Setiap warganegara (baca siswa) diharapkan dapat menganalisis secara intelektual dan ilmiah dan memiliki pendirian ataupun pandangan terhadap suatu isyu atau masalah publik. Pendirian ataupun pandangan itu mencerminkan konsep dan orientasi nilai yang dimiliki, konsep tentang keadilan, hak asasi manusia, dan nilai-nilai yang fundamental dalam masyarakat. Olvier Dan Shaver (Bruce Joyce, 1985:262) menjelaskan bahwa melalui model ini dapat dibentuk tiga kompetensi yaitu pertama kompetensi familiartitas atas nilai-nilai dasar dan konstitusi negara, kedua kompetensi berupa keterampilanketerampilan dalam mengklarifikasi dan memecahkan masalah-masalah yang menjadi isyu pbulik, dan ketiga kompetensi dalam bentuk pengetahuan dan wawasan terhadapmasalah-masalah komtemporer baik dalam bidang politik, pemerintahan maupun isyu-isyu publik.

\section{Strategi mengajar}

Strategi mengajar model ini oleh Oliver dan Shaver (Bruce Joyce, 1985:262) didasarkan pada pemikiran mengenai (1) kelas sebagai model masyarakat, (2) konsepsi mengenai nilai, dan (3) konsepsi mengenai dialog yang produktif. Dalam hubungan dengan pemikiranpemikiran tersebut, maka kegiatan proses pembelajaran terfokus pada (1) menemukan, mengidentifikasi, dan mengkaji serta menganalisis kasus-kasus yang menjadi public isyu baik masalah hukum, politik, pemerintahan, sosial, ekonomi, budaya, dan lain sebagainya, (2) Menemukan dan mengkalrifikasi konsepkonsep nilai yang berkembang atau yang menjadi orientasi perilaku setiap individu, kelompok, ataupun masyarakat, dan (3) proses pembelajaran itu harus berlangsung dalam suatu dialog yang produktif. Pertanyaan-pertanyaan guru didesain untuk mendorong siswa mengemukakan pemikirannya dan membantu mereka belajar. Jadi strategi mengajar model ini lebih ditekankan pada mendorong siswa untuk aktif, menemukan, mengidentifikasi, mengklarifikasi, mengemukakan pemikirannya mengenai kasus-kasus yang menjadi isyu publik.

\section{Konsep Utama Model}

Berdasarkan pemikiran-pemikiran yang menlandasi strategi mengajar, maka konsep utama yang hendak dikembangkan melalui model ini ialah (1) dialog atau model tanya jawab. Dalam dialog ini guru mengajukan pertanyaan kepada siswa untuk dapat menempatkan posisi, posisi, dan pemikirannya terhadap suatu suatu isyu publik, dan mendorong siswa untuk mengemukakan pertimbangan nilai terhadap setiap isyu publik yang diajukannya. (2) Isyu publik yang terfokus pada isyu kebijakan publik. Dalam hubungan ini terhadap setiap isyu publik dapat dikaji siapa yang bertanggungjawab terhadap masalah itu, apakah sudah ada kebijakan publik untuk itu, sejauh mana kebijakan publik itu masih relevan untuk dipertahankan, direvisi, ataupun diganti sama sekali, dan (3) kerangka nilai-nilai dasar seperti keadilan, kebenaran, kejujuran, kesetiaan sebab nilai-nilai dasar ini akan menjadi bagian penting dari upaya guru untuk melihat 
pandangan siswa dan preferensi nilai yang dimiliki oleh siswa, (4) identifkasi problemproblem faktual, dengan melihat apa yang menjadi problem area, menentukan topik-topik yang menjadi fokus masalah, dan melihat konflik-konflik nilai yang terjadi.

\section{Pembelajaran PKn Sebagai Pengajaran Afektif.}

Idealnya setiap guru harus memiliki wawasan yang baik tentag nilai, norma dan moral, sebagai sesuatu yang sangat fundamental dalam pendidikan. Lebih-lebih bagi guru PPKn, guru mata pelajaran yang oleh beberapa pihak dipandang sebagai representative pendidikan moral. Memang dalam rampu-rambu GBPPPPKn kurikulum 1994 dinyatakan bahwa ruang lingkup PPKn meliputi (1) nilai, moral dan norma, (2) kehidupan idiologi, plitik, ekonomi social budaya, pertahanan keamanan, dan perkembanagan iptek. Namun demikian ternyata apa yang tercantum dalam rambu-rambu ruang lingkup tersebut tidak disertai penjelasan apapun serta tidak pernah jelas dalam implementasi pembelajarannya.

Kurikulum 1994 mata pelajaran PPKn dimaksudkan untuk menjawab kritik yang berkembang dimasyarakat bahwa hasil pembelajaran mata pelajaran PPKn selama ini masih bersifat kognitif bahkan verbalistik. Untuk merespon kritik tersebut, pokok-poko bahasan dalam mata pelajaran PPKn kurikulum 1994 kemudian dirumuskan dalam topic-topik nilai (value), bukan topic-topik keilmuan, khususnya ilmu politik dan ilmu hukum. Sebagai contoh adalah topic nilai kepatuhan, bukan norma-norma dalam masyarakat atau lebih khusus norma hukum. Contih lainnya adalah topic nilai musyawarah, bukan sistim demokrasi.

Keluhan umum dari para guru dalam menghadapi pokok bahasan/topic nilai dicontohkan tersebut merupakan konsep yang abstrak, tidak jelas body of knowledge-nya, serta sangat terbatasnya sumber bahan pembelajaran. Keluhan tersebut dapat dipahami, sebab topic-topik nilai tersebut sesungguhnya termasuk dalam kajian filsafat, khususnya filsafat nilai (aksiologi). Sedangkan dalam kajian tradisi persekolahan atau pendidikan formal kita, hingga tingkat perguruan tinggi sekalipun, kajian filsafat kurang memperoleh perhatian yang layak. Berbeda dengan sumber bahan untuk pengembangan topic-topik keilmuan, termasuk ilmu politik dan ilmu hukum, referensinya sangat banyak. Sehingga akibat dari permasalahan yang dikemukakan itu muncullah kondisi yang sangat ironis, yakni ketidak siapan guru dalam pembelajaran dan tidak mustahil terjadi kasus guru "klehabisan" bahan.

Salah satu komponen penting dalam pendidikan adalahb guru yang memiliki kompetensi sesuai dengan standar. Tanpa dimilikinya kompetensi itu, mustahil guru dapat melaksanakan perannya dengan baik yang pada giliran selanjutnya akan mengakibatkan rendahnya kualitas hasil pendidikan. Standar kompetensi guru adalah criteria untuk menentukan kemampuan guru dalam membantu siswa dalam mencapai standar materi dan untuk kerja yang tinggi. Kriteria ini meliputi kemampuannya dalam menyiapkan program pembelajaran, mengkomunikasikan pengetahuannya, ketrampilan-ketrampilan peeagogiknya, dan kemampuan dalam mengikuti perkembangan disiplin akademik dan professional. Secara ringkas kompetensi guru menyangkut dua aspek yakni kompetensi penguasaan bahan ajar dan kompetensi penguasaan pembelajaran.

Kompetensi penguasan bahan ajar dalam PPKn mencakup tiga aspek, yaitu: (1) memahami pengetahuan kewarganegaraan (Civic Knowledge), (2) memahami ketrampilan kewarganegaraan (civic skills), dan (3) memahami etika kewarganegaraan (civic ethics). Aspek pengetahuan kewarganegaraan dan etika kewarganegaraan mencakup bahan ajar tentang nilai, moral dan norma. Disamping mengauasai bahan ajar tersebut, guru hendaknya mampu mengimplementasikannya dalam program pembelajaran.

\section{Materi Pelajaran}

Materi atau bahan pelajaran adalah sarana yang digunakan untuk belajar dalam rangka mencapai tujuan pembelajaran, yang secara eksplisit biasa dirumuskan dalam Tujuan Pembelajaran Khusus (TPK). Materi pelajaran 
tentang nilai dapat dikembangkan dari pokok bahasan dan tujuan pembelajaran yang eksklusif dan spesifik membahas tentang nilai. Di samping itu dapat pula secara inklusif dimasukkan ke dalam pokok bahasan dan tujuan pembelajaran lainnya. Artinya dalam pokok bahasan atau tujuan pembelajaran itu dimunculkan dimensi nilai. Sebagai contoh, pokok bahasan Sistem Politik Demokrasi dapat dikembangkan materi penghargaan terhadap prinsip-prinsip demokrasi (domensi nilai). Sumber bahan dapat berasal dari buku teks, naskah, dokumen, artikel isi pemberitaan surat kabar/radio/televisi, isi video cassete, peristiwaperistiwa aktual yang terjadi dalam masyarakat dan lain-lain. Bahkan pertanyaan atau respon dari para siswa dapat menjadi sumber bahan atau materi pembelajaran.

Beberapa hal yang perlu diperhatikan berkaitan dengan materi pembelajaran adalah: (1) materi pelajaran harus relevan dengan tujuan pembelajaran dilihat dari aspek isi (content) dan cakupannya harus lebih luas, (2) materi pelajaran yang sama dapat digunakan untuk mencapai tujuan pembelajaran yang berbeda, bahkan juga pada pokok bahasan yang berbeda (3) materi pelajaran yang berbeda dapat digunakan untuk mencapai tujuan pembelajaran yang sama, (4) materi pelajaran harus relevan dengan tujuan pembelajaran dilihat dari aspek perilaku (behavior), (5) materi pelajaran dalam hal taraf kesulitannya harus disesuaikan dengan kemampuan siswa, sehingga mereka mampu menerima dan mengolahnya, dan (6) materi pelajaran hemdaknya dapat merangsang motivasi dan partisipasi aktif siswa, antara lain karena relevan dengan pengalaman yang telah mereka miliki, baik dari pengalaman hidup sehari-hari maupun pengalaman belajar.

\section{PEMBAHASAN}

\section{Karakteristik Kompetensi Pembelajaran Jurisprudensi Inkuiri}

Karakteristik pembelajaran

Jurisprudensial Inkuiri sebagai kompetensi dan kapasitas yang hendak dibentuk melalui ketiga aspek yakni kemampuan mencakup masalah, kemampuan mengambil sikap, kemampuan melaksanakan dan memberi penilaian. Temuan penelitian menunjukkan bahwa kompetensi pembelajaran jurisprudensial inkuiri dapat dibentuk melalui berbagai pendekatan atau model pembelajaran. Tingkat capaian kompetensi yang diharapkan dapat dibentuk melalui pembelajaran ketiga aspek ternyata sangat baik dengan tingkat capaian di atas $85 \%$. Capaian ini mengindikasikan beberapa hal penting, yaitu:

a. Bahwa model pembelajaran jurisprudensial inkuiri melalui pengkajian aspek cakupan masalah, sikap siswa dan aspek pelaksanaan penilaian, dapat dikembangkan dan diimplementasikan di sekolah-sekolah.

b. Model-model pembelajaran seperti jurisprudensial inkuiri tersebut mempunyai dampak yang sangat baik terhadap pembentukan kompetensi secara komprehensif. Secara teoritik hal ini dimungkinkan karena orientasi dan penekanan dari masing-masing aspek tersebut adalah siswa belajar aktif. Siswa diberi pengalaman belajar untuk dapat mengidentifikasi sumber-sumber kasus yang memberi implikasi terhadap pengajaran moral dan norma. Kemudian siswa dapat menemukan pilihan nilai yang sesuai dengan problem araes, memiliki kepercayaan diri dalam mengklasifikasi dan mengklarifikasi suatu kasus yang mengandung sejumlah nilai, memiliki komitmen dalam menentukan sikap, memiliki kesadaran diri yang tinggi dalam menerima nilai, siswa lebih bersikap kristis dalam menerima dan menganalisis suatu kasus, siswa memiliki wawasan luas dalam memecahkan berbagai persoalan yang mengajak untuk berada pada alternative pemecahannya, siswa memiliki kemampuan dalam memberi argumentasi dalam menentukan suatu kasus yang dibahas, siswa dapat menunjukkan kemampuan untuk konsekuensi menentukan penilaian.

c. Kompetensi dalam pembelajaran nilai yang terbentuk, memberi peluang bagi pencapaian tujuan kurikulum tingkat satuan pendidikan yang pada intinya memberi peluang ketercapaian kompetensi siswa. Maksudnya bahwa apa yang terkandung dalam kompetensi pembelajaran nilai memberi peluang kepada siswa dalam berbagai matapelajaran untuk dapat bersikap eksis 
dalam mengkaji dan menganalisan serta mengklarifikasi berbagai problem da orientasi serta konsekuensi penilaiannya.

d. Pembelajaran jurisprudensial inkuiri melalui pengkajian aspek cakupan masalah, sikap siswa dan pelaksanaan penilaian memiliki kompetensi yang tidak hanya mempunyai dampak terhadap pembelajaran PKN, tetapi juga dalam proses pembelajaran pada mata pelajaran yang lainnya.

\section{Dampak instruksional}

Model pembelajaran jurisprudensial inkuiri melalui pengkajian tiga aspek dikembangkan memberikan efek instruksional dan dampak pengiring yang cukup baik terhadap sebagaian besar siswa yakni $>85 \%$ siswa. Hasil penelitian tersebut, menunjukkan bahwa dampak instruksional maupun dampak pengiring dari masing-masing aspek yang dikaji tersebut sangat signifikan. Maksudnya masingmasing aspek dalam pembelajaran jurisprudensial inkuiri melalui pengkajian aspek cakupan masalah, sikap siswa, dan peklaksanaan penilaian tersebut secara efektif dapat memberi dampak yang signifikan terhadap pembentukan kompetensi implisit didalamnya dapat menciptakan kondisi belajar mengajar yang diharapkan dalam pembelajaran PKN.

\section{Analisis keteracapaian kompetensi melaui model jurisprudensial inkuiri dalam pembelajaran PPKn}

Pembentukan kompetensi melalui penerapan model pembelajaran jurisprudensial inkuiri menunjukkan bahwa ketercapaian secara komprehensif Kompetensi yang dimaksudkan adalah domain kognitif, domain afektif, dan psikomotor sebagai suatu implementasi dari keterampilan proses. Aspek-aspek tersebut tampak melalui ketercapaian konpetensi yang ada dalam pembelajaran nilai. Analisis model jurisprudensial inkuiri mencakup kemampuankemampuan seperti: 1) kemampuan melakukan orienasi terhadap suatu kasus; 2) kemampuan kemampuan mengidentifikasi masalah; 3) kemampuan dalam penetapan posisi suatu kasus yang merupakan issue publik; 3) kemampuan memberi contod dan argumentasi; 5) kemampuan melakukan pengujian posisi kasus dan 6) kemampuan melakukan pengetesan suatu asumsi. Kemampuan-kemampuan tersebut terealisasi dalam proses pembelajaran PKN di SMA Negeri 10 Manado, dengan indicatorindikatornya yakni siswa menyadari bahwa belajar merupakan suatu kebutuhan, siswa seefisien dan seefektif mungkin menggunakan waktu belajar tanpa harus ada paksaan, selalu memanfaatkan perpustakaan sebagai sarana penunjang pembelajaran. Pada tatanan yang lebih tinggi dapat dicapai kemampuan untuk secara kritis melakukan evaluasi terhadap indicator ketercapaian kompetensi secara komprehensif, menyeleksinya sesuai dengan kebutuhan berdsasarkan penilaian kritis mengenai manfaat serta kegunaan nilai yang diperoleh.

Temuan-temuan penelitian tersebut, menjelaskan beberapa masalah penting untuk dibahas, yaitu pertama, masalah komprehensitas capaian kompetensi dalam pembelajaran. Manfaat penting dari hasil penelitian ini ialah ditemukannya model-model pembelajaran yang secara komprehensif memperkuat pencapaian tujuan pembelajaran. Melalui pengkajian aspek cakupan masalah dapat diperkuat kemampuan siswa dalam menemukan dan memilih suatu kasus sebagai bahan analisis dan stimulus aktif dalam suatu interaksi baik akademik, sosial, maupun emosional. Secara akademik dapat dikembangkan kemampuan penalaran, argumentasi, dan berpikir kritis terhadap berbagai masalah. Secara sosial dapat dibangun dan dikembangkan sikap sosial dan relasi sosial yang kuat melalui kelompok kerja, dan secara emosional dapat dilatih kemampuan untuk saling menghargai, saling memahami, menghormati, dan rasa kebersamaan tim kerja. Demikian juga melalui metode permaian , suatu proses pembentukan kepribadian siswa dengan memungkinkan siswa dapat menangkap, menggali, menginternalisasikan yang pada dasarnya dapat memperkuat pencapaian tujuan pembelajaran. Kemudian pengkajian aspek sikap siswa, dimana yang melibatkan keseluruhan unsur-unsur belajar yang menekankan pada domain afektif yang dapat dikembangkan sebagai aspek nilai, moral dan norma. Kedua, melalui temuan tersebut ditemui 
pula permasalahan mendasar terutama terkait dengan strategi implementasi kurikulum tngkat satuan pendidika. Artinya penerapan modelmodel pembelajaran dalam upaya pencapaian kompetensi dalam pengajaran jurisprudensial inkuiri akan sangat ditentukan oleh kesiapan baik guru maupun siswa serta kondisi lingkungan sekolah, kepemimpinan kepala sekolah serta dukungan guru-guru. Dari faktor kurikulum, penerapan model jurisprudensial inkuiri tersebut membutuhkan waktu, sehingga sangat memerlukan kemampuan guru untuk merancang kegiatan-kegiatan terstruktur di luar jam tatap muka. Di samping itu, ketercapaian materi kurikulum dapat diatasi dengan mengembangkan masalah-masalah secara terintegrated atau terpadu dari beberapa pokok bahasan. Dengan strategi tersebut, dari hasil analisis ketercapaian kompetensi siswa terhadap materi kurikulum berdasarkan ketiga aspek dalam pembelajaran jurisprudensial inkuiri menunjukkan bahwa target kurikulum dapat dicapai, karena melalui proses pembelajaran yang dikembangkan siswa belajar secara komprehensif dan terintegrasi melalui masalahmasalah ataupun tema-tema yang menjadi topik dari suatu pokok bahasan ataupun sub pokok bahasan yang termuat dalam garis-garis besar program pengajaran pendidikan Pancasila dan Kewarganegaraan (PKn).

\section{KESIMPULAN}

Berdasarkan data hasil penelitian dan hasil analisis, maka dapat disimpulkan beberapa hal penting sebagai berikut:

1. Penerapan model Jurisprudensial Inkuiri yang dikembangkan melalui tiga aspek yakni cakupan masalah, sikap siswa dan aspek pelaksanaan penilaian, secara signifikan efektif dan dapat meningkatkan evaluasi proses pada pengajaran $\mathrm{PKN}$, sehingga secara rasional siswa merasa ada kepuasan terhadap asumsi-asumsi yang diajukan.

2. Penerapan model pembelajaran Jurisprudensial Inkuiri dalam kegiatan belajar mengajar di kelas dipengaruhi oleh sejumlah faktor yang determinan. Faktor-faktor tersebut dapat dilihat dari faktor guru, faktor sistem pembelajaran terutama model pembelajaran yang yang direktif, faktor kurikulum, sistem sosial, dan sistem pendukung terutama terkait dengan masalah ketersediaan fasilitas pelaksanaan evaluasi proses.

3. Pengembangan validasi penilaian berbasis portofolio secara signifikan dapat memperkuat ketercapaian evaluasi komprehensif berbasis kompetensi

4. Melalui penerapan model pembelajaran Jurisprudencial Inkuiri, maka dapat engukur pencapaian tujuan pembelajaran yang cukup baik, dimana terdapat konsistensi sikap dan perilaku dengan pertimbangan-pertimbangan untuk pengetesan asumsi dan penyimpulannya.

5. Implikasi penerapan model pembelajaran Jurisprudensial Inkuiri dapat merangkum strategi pengembangan kurikulum tingkat satuan pendidikan yaitu menyangku guru, lingkungan sosial dan sistem pendukung lainnya. Sehingga secara teoretik model pembelajaran jurisprudensial inkuiri ini dapat memperkuat pencapaian kompetensi siswa secara komprehensif, sehingga berpengaruh terhadap evaluasi yang diharapkan.

\section{SARAN}

Berdasarkan pembahasan dan simpulan di atas, maka ada beberapa saran yang dapat dirumuskan sehubungan dengan pengembangan model pembelajaran Jurisprudensial Inkuiri. Adapun saran-saran sebagai berikut:

1. Pengembangan dan penerapan model pembelajaran yang inovatif, mengisyaratkan perlunya persiapan dan kesiapan guru-guru di sekolah. Beberapa aspek yang perlu diperkuat adalah perlunya pendidikan dan latihan bagi guru-guru menyangkut penguasaan landasan-landasan dan asumsiasumsi teoretik mengenai model pembelajaran Jurisprudensial Inkuiri.

2. Penerapan model pembelajaran jurisprudensial inkuiri dapat membentuk suatu kemampuan teknis dalam menyusun dan merencanakan serta mengimplementasi model pembelajaran tersebut, dan kemampuan melakukan evaluasi serta mengembangkan langkah-langkah inovatif.

3. Untuk meningkatkan kualitas guru dapat dilakukan melalui kerjasama kelembagaan 
antara sekolah dengan lembaga pendidikan tenaga kependidikan ataupun melalui dinas pendidikan nasional di setiap daerah. Wadah Musyawarah Guru Mata Pelajaran (MGMP) sekaligus dalam rangka diseminasi modelmodel penilaian yang inovatif.

4. Untuk lembaga pendidikan tenaga kependidikan diperlukan upaya untuk mengkaji kembali kurikulum sehingga ada relevansinya bagi ketercapaian kompetensi mengajar sekaligus ketercapaian pelaksanaan evaluasi yang komprehensif

\section{DAFTAR KEPUSTAKAAN}

Barry K. Beyer, 1979, Teaching Thinking in Social Studies, Mcmillan Publishing, New York

Benny Yiu Ting, 2002, Teaching Portfolio,

Bruce Joyce, 1995, Models of Teaching, Science Resarch Association, Chihago

Charles Quegley, 2000, Global Trend in Civic Education, makalah pada Conference on Civic Educatiuon for Civil Society, CICED and USIS Jakarta, Bandung 16 17 Maret 1999.

Charlotte Trinquet, 2002, Teaching Portfolio,

Cogan John, 1999, Developing the Civil Society: The Role of Civic education, University of Minessota, USA

Donald Ary, Lucy Cheser, 1979, Introduction to Research in Education, Holt Rinehart and Winston, New York

Helen Barrett, The Electronic Portfolio Development Process,

Margareth Stimmann Branson, 1998, The Role of Civic education, Center for Civic Education, USA

Michael, 2002, Dasar-dasar Utama Praktek Belajar Kewarganegaraan, materi pada Pelatihan Pelatih Praktek Belajar Kewarganegaraan, Center for Civic Education Indonesia Project bekerjasama dengan Departemen pendidikan nasional, RI, 5-9 Agustus 2002. ,

Richard H. Hersh, John Miller, Glen Fielding, 1980, Models of Moral Education, Longman Inc, New York. 